\title{
PENGARUH PEMBERIAN VARIAN HERBAL JAHE (Zingiber officinale ) DENGAN AUTOMATIC FEEDER TERHADAP PANJANG TUNGKAI (FEMUR, TIBIA, METATARSO) PADA ITIK (Anas javanicus)
}

\section{The Effect of Ginger Herbal Variation (Zingiber officinale) with Automatic Feeder on Length of Ducks (Anas Javanicus) Limbs (Femur, Tibia, Metatarso)}

\author{
Reni Rakhmawati ${ }^{1)}$, Mei Sulistyoningsih ${ }^{2)}$ \\ Pendidikan Biologi, FPMIPATI, Universitas PGRI Semarang \\ rahmamashuri@yahoo.co.id ${ }^{1)}$, meihadifa@gmail.com ${ }^{2)}$
}

\begin{abstract}
This study aims to determine the effect of giving ginger elephant and ginger empiric herbs by using automatic feeder or manual feed tool to the length of the leg bones (femur, tibia, metatarso) in ducks. This study used randomized randomized controlled trials with four treatments and three repetitions. GP1 (Feed + Automatic Feeder + Elephant Ginger 2\%), GP2 (Feed + Manual + Elephant Ginger 2\%), EPI (Feed + Automatic Feeder + Emprit Ginger 2\%), EP 2 (Feed + Manual + Empritic Ginger 2\%). The parameters measured were the length of the leg bones (femur, tibia, metatarso) of ducks. The results of the analysis showed that the total bone length of the femur was $6.51 \mathrm{~cm}$ with Fcount (0.038) <Ftable (5.32), the total length of the total tibia bone was $11.9 \mathrm{~cm}$ with Fcount $(1,313)<$ Ftable $(5,32)$, and the results of the total length of the metatarso bone are $6.67 \mathrm{~cm}$ with Fcount (0.668)> Ftable (5.32). These results indicate that the effect of giving ginger elephant and empirical ginger using a feed device Automatic feeder or manually has no significant effect $(P>0.05)$ on the length of the leg bones (femur, tibia, metatarso) of ducks. The results are not significantly different which causes the Automatic feeder tool to be a new breakthrough for replacing the manual feed tool for feeding ducks
\end{abstract}

Keywords: Duck, Ginger, Tools, Length Of Legs

\begin{abstract}
ABSTRAK
Penelitian ini bertujuan untuk mengetahui pengaruh pemberian herbal jahe gajah dan jahe emprit dengan menggunakan alat pakan Automatic feeder atau manual terhadap panjang tulang tungkai (femur, tibia, metatarso) pada itik. Penelitian ini menggunakan percobaan acak RAL dengan empat perlakuan dan tiga kali pengulangan. $\mathrm{GP}_{1}\left(\right.$ Pakan + Automatic Feeder + Jahe Gajah 2\%), $\mathrm{GP}_{2}$ $($ Pakan + Manual + Jahe Gajah 2\%), EP 1 (Pakan + Automatic Feeder + Jahe Emprit 2\%), EP 2 (Pakan + Manual + Jahe Emprit2\%). Parameter yang diukur adalah panjang tulang tungkai (femur, tibia, metatarso) itik. Hasil analisis menunjukan bahwa panjang tulang femur total rata-rata yaitu $6,51 \mathrm{~cm}$ dengan $\mathrm{F}_{\text {hitung }}(0,038)<\mathrm{F}_{\text {tabel }}(5,32)$, hasil panjang tulang tibia total rata-rata yaitu11.9 $\mathrm{cm}$ dengan $\mathrm{F}_{\text {hitung }}$ $(1,313)<\mathrm{F}_{\text {tabel }}(5,32)$, dan hasil panjang tulang metatarso total rata-rata yaitu $6.67 \mathrm{~cm}$ dengan $\mathrm{F}_{\text {hitung }}$ $(0,668)>F_{\text {tabel }}(5,32)$. hasil tersebut menunjukan bahwa pengaruh pemberian herbal jahe gajah dan jahe emprit dengan menggunakan alat pakan Automatic feeder atau manual tidak berpengaruh nyata $(\mathrm{P}>0,05)$ terhadap terhadap panjang tulang tungkai (femur, tibia, metatarso) itik. Hasil tidak berbeda nyata ini yang menyebabkan alat Automatic feeder ini bisa menjadi terobosan baru untuk pengganti alat pakan manual untuk pemberian pakan pada itik.
\end{abstract}

Kata kunci : Itik, Jahe, Alat pakan, Panjang Tungkai 


\section{PENDAHULUAN}

Indonesia merupakan negara yang kaya akan sumber daya alamnya terdapat berbagai macam hewan dan tumbuhan dari berbagai daerah di Indonesia. Saat ini populasi itik di Indonesia semakin meningkat, pada tahun 2013 sebanyak 32.129, pada tahun 2014 sebanyak 33.178, pada tahun 2015 sebanyak 34.854, pada tahun 2016 sebanyak 41.867 dan pada tahun 2017 sebanyak 43.156 (Peternakan, 2017). Olahan daging bebek/itik saat ini banyak digemari oleh penggemar kuliner, karena rasa daging bebek sangat lezat dan khas (Ali, 2014). Hasil itik sejauh ini itik tidak sebagus yang diharapkan peternak. Pertumbuhan itik sejauh ini tidak bisa maksimal, karena masih terdapat itik yang pertumbuhannya tidak maksimal. Pertumbuhan dapat diukur dari perubahan bobot badan yang meliputi perubahan bagian-bagian tubuh, tulang, daging dan lemak dengan kecepatan yang berbeda dari tubuh secara keseluruhan (Suryawan et,. al. 2017).

Hasil itik yang baik tidak terlepas dari pertumbuhan tulang, karena pertumbuhan tulang mempengaruhi pertumbuhan daging pula. Tulang itik adalah bagian paling awal terbentuk, sebab sebagai tempat melekatnya otot/daging. Sifat yang berhubungan dengan produktivitas unggas yaitu panjang tibia, lingkar metatarso, lingkar dada, panjang femur dan dada (Hutt, 1949). Ukuran tulang paha, dan shank serta perbandingan antara panjang shank dan lingkar shank menunjukkan nilai-nilai yang efektif untuk pendugaan konformasi tubuh (Nishida et al., 1980).

Pangan asal hewan yang dikonsumsi sehari-hari tentu saja mempunyai resiko menjadi tidak aman karena kemungkinan mengandung bahan berbahaya seperti residu obat hewan, atau bahan kimia berbahaya lainnya. Pengobatan dengan antibiotik selain mahal dapat berdampak negatif terhadap kesehatan apabila produk hasil ternak yang dihasilkan mengandung residu. Hal tersebut kemudian di cegah dengan penambahan ransum pada ternak. Bahan ransum ternak terdiri dari berbagai jenis bahan ransum dengan komposisi tertentu. Herbal untuk ransum pakan contohnya adalah jahe (Zingeber officinale) yang memilki kandungan : vitamin (A, B1, B2, C), karbohidrat, serat, lemak, kalsium, zat besi, sodium, fosfor, protein, dan niasin. Wahju, (2004) menjelaskan jumlah kalsium (Ca), protein, dan fosfor $(\mathrm{P})$ yang seimbang guna dibawa kedalam matrik akan mempengaruhi kepadatan, dan struktur panjang tulang. Kalium, protein dan fosfor guna dalam pembentukan tulang yang optimal

Sekarang zamannya serba mudah dan efisien, termasuk dalam hal penggunaan teknologi pendukung budidaya itik. Urusan cara pemberian pakan menjadi salah satu faktor penting dalam menentukan keberhasilan budidaya (Ali, Hosir, \& Nurlina, 2017). Pemberian pakan harus dilakukan secara teratur, sayangnya hal ini kadang terlupakan oleh para peternak dan menyebabkan menurunnya hasil panen.Alat automatic feeder merupakan alat pakan otomatis yang mempermudah peternak dalam budidaya. Perangkat automatic feeder yang memiliki lubang tempat keluarnya pakan dibagian bawah body utama alat tersebut, sehingga dengan pemberian pakan seberat $5 \mathrm{~kg}$ akan menimbulkan tekanan terlalu besar pada tutup lubang tersebut. Alat ini diharapkan memberikan pakan sesuai kebutuhan itik dan kesanggupan itik untuk pertumbuhan dan memaksimalkan bobot pada itik.

\section{METODE PENELITIAN}

Wilayah lokasi penelitian ini adalah di daerah Bambu Asri Perumahan Plamongan Indah Kecamatan Semarang Timur, Kota Semarang. Waktu pelaksanaan penelitian ini dilaksanakan pada bulan November 2017 sampai Januari 2018. Subjek dalam penelitian ini adalah DOD (Day Old Duck) Itik Magelang. Penelitian ini menggunakan Rancangan Acak Lengkap (RAL) dengan pola factorial $2 \times 2$ dengan faktor A pemberian herbal jahe gajah dan jahe emprit sedangkan faktor B penggunaan alat pakan automatic feeder dan manual, sehingga terdapat 4 perlakuan dengan masing-masing 3 kali pengulangan. Penelitian ini dilakukan dengan pemeliharaan dua periode, yaitu : Periode 
brooding (itik datang sampai umur 21 hari) dan Periode finisher (itik umur 21 sampai 45 hari). Tahap periode finisher ini ada thermostat dan termometer sebagai pengaturan suhu ruangan. Kandang yang digunakan sesuai dengan design penelitian yaitu dengan 4 kandang yang susunannya yaitu kandang GP1 dengan alat automatic feeder dan jahe gajah $2 \%$, kandang GP2 dengan manual dan jahe gajah $2 \%$, kandang EP1 dengan alat automatic feeder dan jahe emprit 2\%, kandang EP2 dengan manual dan jahe emprit $2 \%$. Pemberian pakan dilakukan sehari 2 kali pagi pukul 06.00 wib dan sore pukul 16.00 wib. Pengambilan data dalam penelitian ini ketika itik umur 45 hari, yaitu dengan mengukur dengan jangka sorong panjang tungkai (femur, tibia, metatarso) pada itik. Hasil yang di dapatkan yaitu panjang tulang femur, tibia, dan metatarso akan di olah dengan menggunakan sidik ragam (ANOVA), apabila terdapat perbedaan maka akan dilakukan dengan uji lanjutan antar perlakuan dengan model Duncan. Analisis data yang digunakan yaitu dengan uji ANOVA Dua Arah (Two Way ANOVA).

\section{HASIL DAN PEMBAHASAN}

Berdasarkan hasil penelitian yang telah dilalukam dapat diperoleh hasil penelitian mengenai pengaruh pemberian varian herbal jahe (Zingiber officinale) dengan automatic feeder terhadap panjang tungkai ( femur, tibia, metatarso) pada itik ( Anas javanicus) :

\section{Panjang Ruling Femur}

Tabel 1. Data hasil rataan panjang tulang femur pada Itik.

\begin{tabular}{|c|c|c|c|}
\hline \multirow{2}{*}{ Herbal } & \multicolumn{2}{|c|}{ Alat Pakan } & \multirow{2}{*}{ Total } \\
\hline & P1 & $\mathrm{P} 2$ & \\
\hline $\begin{array}{c}\text { (G)Jahe Gajah } \\
2 \%\end{array}$ & 6,3 & 6,51 & 6,44 \\
\hline $\begin{array}{c}\text { (E)Jahe Emprit } \\
2 \%\end{array}$ & 6,47 & 6,68 & 6,57 \\
\hline Rerata Umum & 6,42 & 6,60 & 6,51 \\
\hline
\end{tabular}

Keterangan:

$\mathrm{GP}_{1}$ : Pakan + Automatic Feeder + Jahe Gajah 2\%

$\mathrm{GP}_{2}:$ Pakan + Manual + Jahe Gajah 2\%

$\mathrm{EP}_{1}$ : Pakan + Automatic Feeder + Jahe Emprit 2\%

$\mathrm{EP}_{2}:$ Pakan + Manual + Jahe Emprit 2\%
Tabel 2. Analisis Sidik Ragam (RAL) Faktorial 2x2 terhadap panjang femur

\begin{tabular}{cccccc}
\hline SK & DB & JK & KT & $\begin{array}{c}F \\
\text { Hitung }\end{array}$ & $\begin{array}{c}F \\
\text { Tabel } \\
5 \%\end{array}$ \\
\hline Perlakuan & 3 & 0,150 & 0,050 & 0,634 & 4,07 \\
Herbal & 1 & 0,092 & 0,092 & 0,695 & 5,32 \\
Alat & 1 & 0,055 & 0,055 & 1,168 & 5,32 \\
Herbal*Alat & 1 & 0,003 & 0,003 & 0,038 & 5,32 \\
& & & & & \\
Galat & 8 & 0,63 & 0,105 & & \\
\hline Total & 11 & 0,779 & & & \\
\hline
\end{tabular}

\section{Panjang Tulang Tibia}

Tabel 3. Data hasil rataan panjang tulang tibia pada Itik

\begin{tabular}{|c|c|c|c|}
\hline \multirow{2}{*}{ Herbal } & \multicolumn{2}{|c|}{ Alat Pakan } & \multirow{2}{*}{ Total } \\
\hline & P1 & P2 & \\
\hline (G)Jahe gajah 2\% & 11,25 & 11,64 & 11,44 \\
\hline (E)Jahe Emprit 2\% & 11,61 & 11,66 & 11,63 \\
\hline Rerata Umum & 11,43 & 11,65 & 11,9 \\
\hline \multicolumn{4}{|l|}{ Keterangan : } \\
\hline \multirow{3}{*}{\multicolumn{4}{|c|}{$\begin{array}{l}\mathrm{GP}_{1}: \text { Pakan + Automatic Feeder + Jahe Gajah } 2 \% \\
\mathrm{GP}_{2}: \text { Pakan + Manual + Jahe Gajah } 2 \% \\
\mathrm{EP}_{1}: \text { Pakan + Automatic Feeder + Jahe Emprit } \\
\\
\quad 2 \%\end{array}$}} \\
\hline & & & \\
\hline & & & \\
\hline : Pakan + Man & & & \\
\hline
\end{tabular}

Tabel 4. Analisis Sidik Ragam (RAL) Faktorial $2 \times 2$ terhadap panjang femur

\begin{tabular}{|c|c|c|c|c|c|}
\hline SK & $\begin{array}{l}\text { D } \\
\text { B }\end{array}$ & JK & KT & $\begin{array}{c}\mathrm{F} \\
\text { Hitung }\end{array}$ & $\begin{array}{c}\text { F Tabel } \\
5 \%\end{array}$ \\
\hline Perlakuan & 3 & 0,342 & 0,114 & 1,694 & 4,07 \\
\hline Herbal & 1 & 0,147 & 0,147 & 2,189 & 5,32 \\
\hline Alat & 1 & 0,106 & 0,106 & 1,580 & 5,32 \\
\hline Herbal*Alat & 1 & 0,088 & 0,088 & 1,313 & 5,32 \\
\hline Galat & 8 & 0,539 & 0,067 & & \\
\hline Total & 1 & 881 & & & \\
\hline
\end{tabular}

\section{Panjang Tulang Metatarso}

Tabel 5. Data hasil rataan panjang tulang metatarso pada Itik

$\begin{array}{rrr}\text { Terbal } & \text { Alat Pakan } & \begin{array}{r}\text { Total } \\ \text { rerata }\end{array}\end{array}$




\begin{tabular}{cccc}
\cline { 4 - 4 } \cline { 4 - 4 } $\begin{array}{cccc}\text { (G)Jahe gajah } \\
2 \%\end{array}$ & 6,69 & 6,61 & $\mathbf{6 , 6 5}$ \\
$\begin{array}{c}\text { (E)Jahe Emprit } \\
2 \%\end{array}$ & 6,68 & 6,72 & $\mathbf{6 , 7}$ \\
\hline $\begin{array}{c}\text { Rerata Umum } \\
\text { Re,69 }\end{array}$ & $\mathbf{6 , 6 6}$ & 6,67
\end{tabular}

Keterangan :

$\mathrm{GP}_{1}$ : Pakan + Automatic Feeder + Jahe Gajah 2\%

$\mathrm{GP}_{2}:$ Pakan + Manual + Jahe Gajah $2 \%$

$\mathrm{EP}_{1}$ : Pakan + Automatic Feeder + Jahe Emprit 2\%

$\mathrm{EP}_{2}$ : $\quad$ Pakan + Manual + Jahe Emprit 2\%

Tabel 6. Analisis Sidik Ragam (RAL) Faktorial 2x2 terhadap panjang femur

\begin{tabular}{cccccc}
\hline \multirow{2}{*}{ SK } & \multirow{2}{*}{ DB } & \multirow{2}{*}{ JK } & KT & $\begin{array}{c}\text { F } \\
\text { Hitung }\end{array}$ & Tabel \\
& & & & \\
\hline Perlakuan & 3 & 0,020 & 0,007 & 0,428 & 4,07 \\
Herbal & 1 & 0,001 & 0,001 & 0,092 & 5,32 \\
Alat & 1 & 0,008 & 0,008 & 0,524 & 5,32 \\
Herbal*Alat & 1 & 0,010 & 0,010 & 0,668 & 5,32 \\
Galat & 8 & 0,15 & 0,025 & & \\
\hline Total & 11 & 0,142 & & & \\
\hline
\end{tabular}

\section{PEMBAHASAN}

\section{Panjang Tulang Femur}

Hasil dari data rataan pada tabel 1 ternyata hampir sama dengan panjang tulang femur itik pada normal. Pada peneletian sebelumnya di ketahui panjang tulang femur normal tanpa perlakuan menghasilkan rata-rata $6,42 \mathrm{~cm}$ (Anas, 2015).

Berdasarkan perhitungan sidik ragam keempat perlakuan pada tabel 2 terhadap panjang tulang femur diketahui bahwa perlakuan herbal (jahe gajah dan jahe emprit) dengan alat (automatic feeder dan manual) memiliki $\mathrm{F}_{\text {hitung }}$ $(0,038)<\mathrm{F}_{\text {tabel }}(5,32)$, hal ini menunjukkan bahwa H0 yang menyatakan "Tidak ada interaksi antara herbal jahe gajah danjaheempritmelalui penggunaan automatic feederatau manual terhadap panjang femur pada itik (Anas javanicus)" diterima, jadi tidak ada efektivitas keempat perlakuan yang meliputi GP1, GP2, EP1, dan EP2 terhadap panjang tungkai pada femur.
Suhu harian di daerah tropis pada siang hari dapat mencapai $34^{\circ} \mathrm{C}$. Faktor penghambat pertumbuhan juga dipengaruhi oleh suhu. Agar terjadi keseimbangan panas daiam tubuh sehingga dicapai suhu tubuh yang relatif konstan, maka kelebihan panas dibuang, juga panas yang diproduksi dalam tubuh itik. Beberapa usaha dilakukan itik antara lain meningkatkan pengeluaran panas dari tubuh terutama melalui mulut, meningkatkan konsumsi air minum dan mengurangi konsumsi rasum. Akibatnya akan terjadi penurunan dalam pertumbuhan (Kusnadi, 2008).

Herbal jahe tidak berpengaruh terhadap panjang tulang femur itik dikarenakan jahe yang digunakan pada penelitian ini yaitu jahe gajah dan jahe emprit. Jahe gajah dan jahe emprit diketahui memiliki kandungan kalsium dan fosfor yang mendekati sama, yaitu pada 100 gram jahe gajah kandunagn kalsium $16 \mathrm{mg}$, fosfor : $34 \mathrm{mg}$ dan pada 100 gram jahe emprit : kalsium $21 \mathrm{mg}$, fosfor : $39 \mathrm{mg}$ sehingga hasil panjang tulang femur tidak berbeda nyata.

Alat pakan pada penelitian ini yaitu automatic feeder dan manual. Hasil dari alat automatic feeder dan manul pada tulang femur hampir mendekati sama, hal ini membuktikan alat automatic feeder ini bisa menggantikan alat pakan manual, karena mampu mengimbangi alat pakan manual. Alat pakan automatic feeder akan sangat berguna karena bisa menghemat tenaga maupun dana dalam budidaya itik.

\section{Panjang Tulang Tibia}

Hasil dari data rataan pada tabel 3 panajang tulang tibia ternyata hampir sama dengan panjang tulang tibia itik pada normal. Pada peneletian sebelumnya di ketahui panjang tulang tibia normal tanpa perlakuan menghasilkan menghasilkan rata-rata maksimum $11,55 \mathrm{~cm}$ (Suryawan, 2017)

Berdasarkan perhitungan sidik ragam keempat perlakuan pada tabel 4 terhadap panjang tulang tibia diketahui bahwa perlakuan herbal (jahe gajah dan jahe emprit) dengan alat (automatic feeder dan manual) memiliki $\mathrm{F}_{\text {hitung }}$ $(1,131)<$ Ftabel $(5,32)$, hal ini menunjukkan bahwa $\mathrm{H}_{0}$ yang menyatakan "Tidak ada interaksi 
antara herbal jahe gajahdanjaheemprit melalui penggunaan automatic feederatau manual terhadap panjang itik pada itik (Anas javanicus)" diterima yaitu tidak ada efektivitas keempat perlakuan yang meliputi GP1, GP2, EP1, dan EP2 terhadap panjang tibia pada itik.

Suhu harian di daerah tropis pada siang hari dapat mencapai $34^{\circ} \mathrm{C}$. Faktor penghambat pertumbuhan juga dipengaruhi oleh suhu. Agar terjadi keseimbangan panas daiam tubuh sehingga dicapai suhu tubuh yang relatif konstan, maka kelebihan panas dibuang, juga panas yang diproduksi dalam tubuh itik. Beberapa usaha dilakukan itik antara lain meningkatkan pengeluaran panas dari tubuh terutama melalui mulut, meningkatkan konsumsi air minum dan mengurangi konsumsi rasum. Akibatnya akan terjadi penurunan dalam pertumbuhan (Kusnadi, 2008).

Herbal jahe tidak berpengaruh terhadap panjang tulang tibia itik dikarenakan jahe yang digunakan pada penelitian ini yaitu jahe gajah dan jahe emprit. Jahe gajah dan jahe emprit diketahui memiliki kandungan kalsium dan fosfor yang mendekati sama, yaitu pada 100 gram jahe gajah kandungann kalsium 16 mg dan fosfor: $34 \mathrm{mg}$ sedangkan pada 100 gram jahe emprit : kalsium $21 \mathrm{mg}$, dan fosfor : $39 \mathrm{mg}$, sehingga hasil panjang tulang tibia tidak berbeda nyata.

Alat pakan pada penelitian ini yaitu automatic feeder dan manual. Hasil dari alat automatic feeder dan manul pada tulang tibia hampir mendekati sama, hal ini membuktikan alat automatic feeder ini bisa menggantikan alat pakan manual, karena mampu mengimbangi alat pakan manual. Alat pakan automatic feeder akan sangat berguna karena bisa menghemat tenaga maupun dana dalam budidaya itik.

\section{Panjang Tulang Metatarso}

Hasil dari data rataan pada tabel 5 panjang tulang metatarso ternyata hampir sama dengan panjang tulang metatarso itik pada normal. Pada peneletian sebelumnya di ketahui panjang tulang metatarso itik pada normal. Pada peneletian sebelumnya diketahui panjang tulang metatarso itik normal tanpa perlakuan menghasilkan ratarata maksimum 6,20 cm (Suryawan edi, 2017).

Berdasarkan perhitungan sidik ragam keempat perlakuan terhadap panjang tulang metatarso diketahui bahwa perlakuan herbal (jahe gajah dan jahe emprit) dengan alat (automatic feeder dan manual) memiliki Fhitung $(0,668)<$ Ftabel $(5,32)$ hal ini menunjukkan bahwa H0 diterima, yang menyatakan "Tidak ada interaksi antara herbal jahe gajah dan jahe emprit melalui penggunaan automatic feeder atau manual terhadap panjang metatarso pada itik (Anas javanicus)", jadi tidak ada efektivitas keempat perlakuan yang meliputi GP1, GP2, EP1, dan EP2 terhadap panjang metatarso pada itik.

Suhu harian di daerah tropis pada siang hari dapat mencapai $34^{\circ} \mathrm{C}$. Faktor penghambat pertumbuhan juga dipengaruhi oleh suhu. Agar terjadi keseimbangan panas daiam tubuh sehingga dicapai suhu tubuh yang relatif konstan, maka kelebihan panas dibuang, juga panas yang diproduksi dalam tubuh itik. Beberapa usaha dilakukan itik antara lain meningkatkan pengeluaran panas dari tubuh terutama melalui mulut, meningkatkan konsumsi air minum dan mengurangi konsumsi rasum. Akibatnya akan terjadi penurunan dalam pertumbuhan (Kusnadi, 2008).

Herbal jahe tidak berpengaruh terhadap panjang tulang metatarso itik dikarenakan jahe yang digunakan pada penelitian ini yaitu jahe gajah dan jahe emprit. Jahe gajah dan jahe emprit diketahui memiliki kandungan kalsium dan fosfor yang mendekati sama, yaitu pada 100 gram jahe gajah kandungan kalsium 16 mg dan fosfor : $34 \mathrm{mg}$ sedangkan pada 100 gram jahe emprit : kalsium $21 \mathrm{mg}$, dan fosfor : $39 \mathrm{mg}$, sehingga hasil panjang tulang metatarso tidak berbeda nyata.

Alat pakan pada penelitian ini yaitu automatic feeder dan manual. Hasil dari alat automatic feeder dan manul pada tulang metatarso hampir mendekati sama, hal ini membuktikan alat automatic feeder ini bisa menggantikan alat pakan manual, karena mampu mengimbangi alat pakan manual. Alat pakan automatic feeder akan sangat berguna karena 
bisa menghemat tenaga maupun dana dalam budidaya itik.

\section{KESIMPULAN DAN SARAN}

Hasil dari penelitian ini Tidak ada interaksi antara herbal jahe gajah melalui penggunaan automatic feeder atau manual terhadap panjang metatarso pada itik (Anas javanicus), tapi pada Alat pakan automatic feeder dan manual hampir mendekati sama, hal ini membuktikan alat automatic feeder ini bisa menggantikan pakan automatic feeder dan bisa jadi terobosan baru pada budidaya itik.

Perlu dilakukan penelitian lebih lanjut tentang pemberian dosis dan perbedaan waktu penggunaan alat pakan automatic feeder untuk parameter yang sama dan Perlu dilakuan penelitian lebih lanjut tentang variasi herbal jahe yang berbeda dan dengan dosis yang berbeda

\section{DAFTAR PUSTAKA}

Akhadiarto, S. 2002. Kualitas fisik daging itik pada berbagai umur pemotongan. Pusat Pengkajian dan Penerapan Teknologi Budidaya Pertanian. BPPT, Bogor.

Hutt, F.B. 1949. Genetics of The Fowl. 1st, Ed., McGraw Hill Book Co, New York.

Ali, M. (2014). AGRIBISNIS “BEBEK SINJAY”

DALAM PERSPEKTIF KEWIRAUSAHAAN

DAN PEMASARAN.

Ali, M., Hosir, A., \& Nurlina, N. (2017).

PERBEDAAN JUMLAH BIBIT PER

LUBANG TANAM TERHADAP

PERTUMBUHAN DAN HASIL TANAMAN

PADI (Oryza sativa L.) DENGAN

MENGGUNAKAN METODE SRI. Gontor

AGROTECH Science Journal, 3(1), 1-21.

Nishida, T., K. Nozawa, K. Kondo,S.S, Mansjoer and HMartojo. 1980. Morphological and genetical studies in the Indonesian Native fowl. The Origin and phylogeny of Indonesia Native livestock. 3:73-83

Sulistyoningsih, M., Rakhmawati, R., dan Mukhtar, A. (2016). Peningkatan Kualitas Bobot Badan dan Karkas dengan Tambahan Herbal pada
Bebek Pedaging. Porsiding Seminar Nasional LPPM Universitas PGRI Semarang, 68-72 ISSN: 978-602-14020-3-0.

Suryawan, E., Sampurna. P., dan Suatha. K. 2017. Pola Pertumbuhan Dimensi Panjang Alat Gerak Tubuh Itik Bali Betina. Fakultas Kedokteran Hewan, Universitas Udayana 9 (2) : 184-185. pISSN: 2085-2495; eISSN: 2477-2712

Wahju. 2004. Ilmu Nutrisi Unggas. Yogyakarta: Universitas Gajah Mada Press. 